\title{
The effect of sex and terminal sire line on carcass characteristics of pork belly
}

\author{
Ivan Bahelka, Marta Oravcová, Emília Hanusová and Peter Demo
}

Department of Animal Breeding and Products Quality, Animal Production Research Centre, Lužianky, Slovak Republic

\begin{abstract}
The objective of study was to evaluate the effect of sex and terminal sire line on pork belly composition of commercially produced pigs. The animals were progeny of White Meaty sows and three terminal sire lines: $\mathrm{HA} \times \mathrm{PN}, \mathrm{LA}$ and YOXPN. Barrows: gilts ratio was 97:102. Pigs were slaughtered at average carcass weight $85.73-89.0 \mathrm{~kg}$ according to genotype. Day after slaughter, the dissection of right half sides was done. After that, the detailed dissection of trimmed belly to individual tissues (bones, meat, fat and skin) was performed. The effect of sex on belly characteristics was significant. Gilts had higher meat proportion in belly than barrows (51.41 vs. $47.21 \%$ ), which reached higher content of subcutaneous and intermuscular fat (43.92 vs. $38.83 \%)$. The influence of terminal sire line was also significant. All differences were found between HaxPN genotype and other two terminal sire lines. Progeny of HAXPN sire line had the highest percentage of meat in belly $(51.28 \%)$ while progeny of YO $\times$ PN had the highest content of fat and skin ( $42.79 \%)$ and bones in belly $(9.48 \%)$.
\end{abstract}

Keywords: pigs, carcass, sex, terminal sire line, pork belly

\section{Zusammenfassung}

\section{Einfluss von Geschlecht und Endstufeneberlinie auf die Schlachtkörpermerkmale von Schweinebauch}

Das Ziel dieser Studie bestand in der Prüfung des Einflusses von Geschlecht und Endstufeneberlinie auf die Zusammensetzung des Bauches von Schlachtschweinen. Die Tiere waren Nachkommen von White Meaty Sauen und Ebern der Endstufenlinien HA×PN, LA sowie YOXPN. Das Verhältnis von Börgen zu weiblichen Tieren betrug 97:102. Geschlachtet wurden die Tiere abhängig vom Genotyp bei einem Schlachtkörpergewicht von 85,73 bis $89,00 \mathrm{~kg}$. Am Tag nach der Schlachtung erfolgte die Zerlegung der rechten Hälfte sowie die Teilstückzerlegung des Bauches (Knochen, Fleisch, Fett, Haut). Der Einfluss des Geschlechtes auf die Bauchmerkmale war signifikant. So zeigten die weiblichen Tiere gegenüber den Börgen einen signifikant höheren Fleischanteil (51,41 bzw. 47,21\%) während Börge einen höheren Gehalt an Unterhaut- und intramuskulärem Fett (43,92 bzw. 47,21 \%) aufwiesen. Der Einfluss der Eberlinie war ebenfalls signifikant. So unterschieden sich die Nachkommen des HAxPN Genotyps mit einem Bauchfleischanteil von 51,28\% gegenüber den zwei weiteren Eberlinien, während die Nachkommen von YOXPN mit 42,79\% signifikant den höchsten Gehalt an Fett und Haut und einem Knochenanteil im Bauch von 9,48\% aufwiesen. 
Schlüsselwörter: Schwein, Schlachthälfte, Geschlecht, Endstufeneberlinie, Bauch

\section{Introduction}

Due to consumer demands for leaner meat products, the aim of pig production has been to reduce body fat and increase lean meat content in carcasses (Stites et al. 1991). One important part of the pork carcass is the belly. In currently produced pigs, lean meat percentage of pork belly has large economic effect for the processing industry and consumer's popularity.

Over the last 40 years, belly lost almost $29 \%$ of fat and became thinner and softer and lower processing yields (Lévesque 2003, Person et al. 2005). A lean meat content exceeding $50 \%$ of pork belly weight is considered as a favourable belly composition (Pulkrábek et al. 1998). This fact is closely connected with evaluation of pig carcasses based on lean meat content (Vališ et al. 2005). Study on pork belly characteristics showed higher lean meat deposition in gilts and boars compared to barrows (Correa et al. 2008, Lo Fiego et al. 1992).

Among the various fat depots in pig carcasses, it is the belly which has been affected the most by the selection to decrease the fatness level of the pig carcass and to improve the belly without affecting lean yield (Marcoux et al. 2007, Schinckel et al. 2002). Suitability of selection for lean meat in the belly is suggested by coefficient of heritability in the studies of Hermesch (2008), $\mathrm{h}^{2}=0.23-0.34$ and Tholen et al. (2001), $\mathrm{h}^{2}=0.27-0.31$.

The aim of this study was to evaluate the effect of some factors on pork belly composition of commercially produced pigs.

\section{Material and methods}

Carcass composition of pig bellies of three genotypes was investigated. Pigs were progeny of White Meaty sows and three different terminal sire lines: $(H A \times P N), n=78 ; L A, n=66$ and $(\mathrm{YO} \times \mathrm{PN}), \mathrm{n}=55$. Barrows: gilts ratio was 97:102. Pigs were slaughtered in experimental abbatoir of the Animal Production Research Centre in Nitra. The average carcass weight (CW) was $89.0,86.17$ and $85.73 \mathrm{~kg}$ according to genotypes. Day after slaughter, the dissection of right half sides to partial carcass parts was done. After that, the detailed dissection of trimmed belly (Walstra \& Merkus 1995) to individual tissues (bones, meat, intermuscular and subcutaneous fat with skin) was performed.

The percentages of single tissues from weight of trimmed belly were calculated. The following carcass traits were analysed: carcass weight (CW), backfat thickness (BF), lean meat percentage (LMP), weight of belly (WB), meat of the belly, fat and skin of the belly, bones of the belly, percentage of belly (from CW), percentage of meat in the belly, percentage of fat and skin in the belly, percentage of bones in the belly.

Statistical package SAS/STAT v. 9.1.3 (SAS 2002/2003) was employed in the analyses. Basic statistics was done using MEANS procedure. CORR procedure was used to calculate Pearson's correlation coefficients between the traits under study. The effect of terminal sire line, sex, carcass weight and weight of belly was investigated using GLM procedure according to the following model equations:

$$
y_{i j}=\mu+S_{i}+G_{j}+b w_{i j}+e_{i j}
$$


where $y_{i j}$ is the dependent variable: weight of belly, kg; meat of belly, kg; fat and skin of belly, $\mathrm{kg}$; bones of belly, $\mathrm{kg}$; percentage of belly, \%; $\mu$ is the intercept, $\mathrm{S}_{i}$ is the fixed effect of sex, (barrow, gilt), $\Sigma S_{i}=0 ; G_{i}$ is the fixed effect of sire's genotype (HAPN, LA, YPN), $\Sigma G_{i}=0 ; b$ is the linear regression coefficient of dependent variable (weight of belly, meat of belly, fat and skin of belly, bones of belly, percentage of belly) on carcass weight $w_{i j}$ and $e_{i j}$ is the random error; $e_{i j} \sim N\left(0, \sigma_{e}^{2}\right)$.

$$
y_{i j}=\mu+S_{i}+G_{j}+b l_{i j}+e_{i j}
$$

where $y_{i j}$ is the dependent variable: meat of belly percentage, fat and skin of belly percentage, bones of belly percentage, $\mu$ is the intercept, $S_{i}$ is the fixed effect of sex (barrow, gilt), $\sum S_{i}=0$; $G_{j}$ is the fixed effect of sire's genotype (HAPN, LA, YPN), $\sum_{j} G_{j}=0 ; b$ is the linear regression coefficient of dependent variable (meat of belly percentage, fat and skin of belly percentage, bones of belly percentage) on weight of belly $l_{i j}$ and $e_{i j}$ is the random error; $e_{i j} \sim N\left(0, \sigma_{e}^{2}\right)$.

\section{Results and discussion}

Basic statistics of whole dataset is given in Table 1. Weight of meat in the belly represents almost $50 \%$ of weight of belly. Average lean meat percentage reached $56.72 \%$ (class E) which documents a good meatiness of pigs observed.

Table 1

Basic statistics for carcass and belly traits

\begin{tabular}{lcccc}
\hline Trait & Mean & SD & Min & Max \\
\hline Carcass weight, kg & 87.20 & 7.26 & 70.00 & 106.00 \\
Backfat thickness, mm & 27.21 & 5.00 & 16.72 & 39.74 \\
Lean meat percentage, \% & 56.72 & 3.98 & 45.68 & 66.23 \\
Weight of belly, kg & 4.87 & 0.69 & 3.07 & 7.64 \\
Meat of belly, kg & 2.40 & 0.35 & 1.63 & 3.32 \\
Fat and skin of belly, kg & 2.02 & 0.53 & 0.60 & 3.54 \\
Bones of belly, kg & 0.45 & 0.16 & 0.19 & 0.87 \\
Percentage of belly, \% & 11.24 & 1.23 & 8.44 & 17.15 \\
Percentage of meat in belly, \% & 49.57 & 6.15 & 33.94 & 65.12 \\
Percentage of fat and skin in belly, \% & 41.15 & 6.72 & 24.95 & 58.55 \\
Percentage of bones in belly, \% & 9.17 & 1.83 & 4.10 & 16.54 \\
\hline
\end{tabular}

SD: standard deviation

Statistically significant or highly significant effect of sex on all observed carcass characteristics of belly except for weight of bones in belly was determined (Table 2). Barrows had higher weight of belly than gilts. Stupka et al. (2004a) also reported higher weight of belly in barrows than gilts (4.35 vs. $4.12 \mathrm{~kg}$ ). Żak \& Tyra (2006) found lower weight of belly in gilts of Polish $\mathrm{LW} \times$ Polish Landrace $(4.05 \mathrm{~kg})$ than that in our study. Barrows reached higher percentage of belly from carcass weight than gilts. This result is in agreement with findings of Stupka et al. (2004a) who state $9.96 \%$ in barrows and $9.56 \%$ in gilts. Similar values have been described by Pulkrábek et al. (2006), from 9.74 to $10.74 \%$ according to carcass lean meat proportion. They state decreasing percentage of belly with increasing carcass lean meat proportion. 
Table 2

Least-squares means and standard errors (sex and sire's genotype effects)

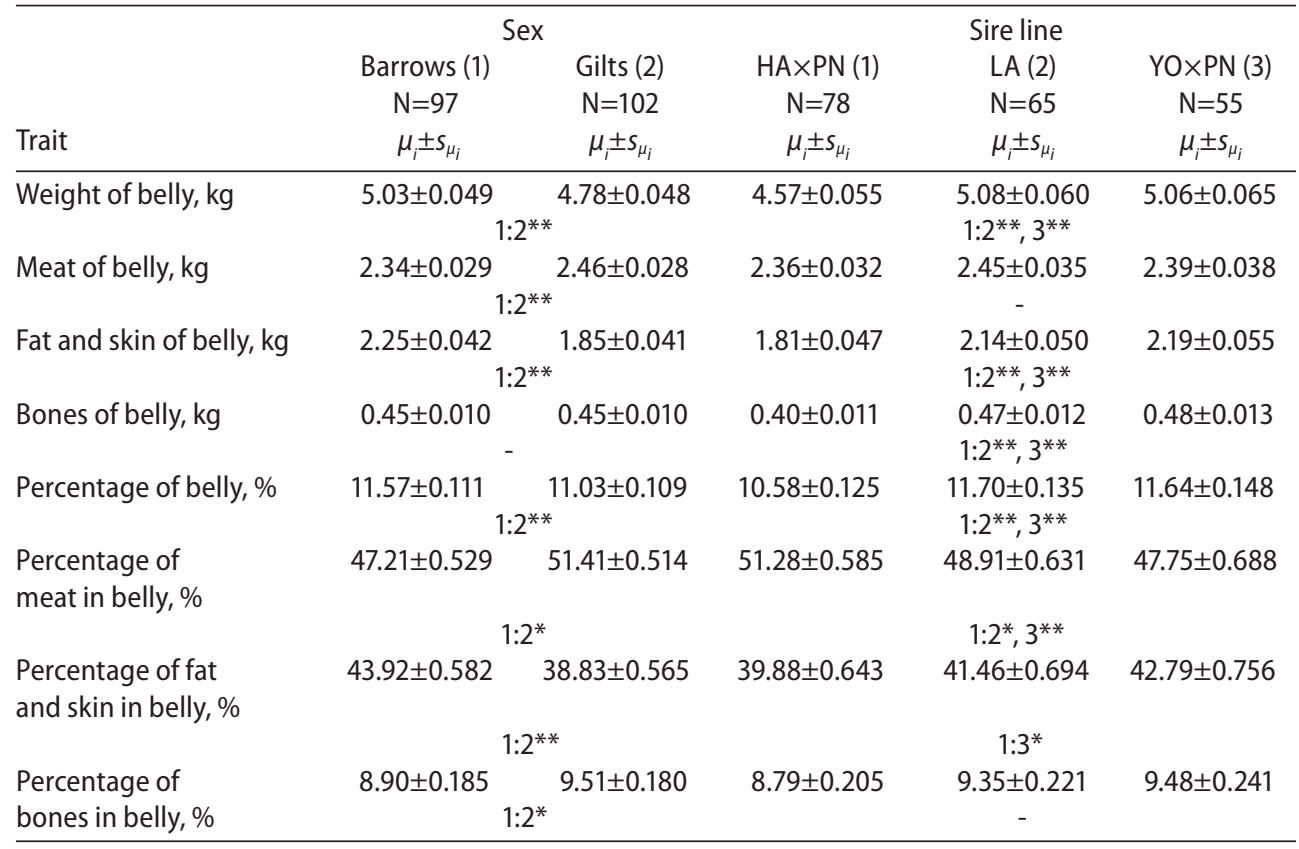

${ }^{*} P<0.01,{ }^{*} P<0.05$ (Scheffe's test), N: number of observations

On the other hand, gilts in our study had significantly higher weight of meat in belly and percentage of meat and bones in belly than barrows. Similarly, Stupka et al. (2004a) found significantly higher proportion of meat in gilts (by $3.32 \%$ ) compared to barrows. In our study, this difference was $4.20 \%$ in favour of gilts. In another study, Stupka et al. (2004b) state that increasing meat proportion of carcass, the weight and percentage of meat in the belly were increasing. This is in agreement with results of Pulkrábek et al. (2006). Higher meat proportion in the belly of gilts than in our study is reported by Żak \& Tyra (2006): $52.79 \%$ and Vališ et al. (2005): $55.17 \%$. Softer bellies of gilts than those of barrows were found by Correa et al. (2008). Vališ et al. (2005) suggested that belly composition is mainly influenced by the lean meat proportion of carcass, and effect of sex (and slaughter weight) is much more important than influence of the hybrid combination.

In the present study, the effect of terminal sire line was evident in all carcass characteristics of belly except for weight of meat and percentage of bones in the belly (Table 2). The effect of genotype on weight of belly was investigated by Tholen et al. (2003). The significant differences between genotypes were similar to those reported in our study (about $0.5 \mathrm{~kg}$ ). The proportions of individual tissues in the belly were observed by Vališ et al. (2005) according to different sire genotype ( $L W \times$ synthetic line, $D \times P N$ and $H A \times P N)$. They found higher proportion of meat in the belly (51.59-53.80\%) but lower percentage of bones (7.13$7.60 \%$ ) and of fat with skin (38.11-40.56\%) in comparison with our results.

Adjustments for considered effects diminished standard deviations of weight of belly from 0.689 to 0.483 , for meat of belly from 0.345 to 0.299 , for fat and skin of belly from 0.525 
to 0.407 and for bones of belly from 0.159 to 0.093 . $R^{2}$ ranged from 0.322 to 0.520 for weight of belly, meat of belly and fat and skin of belly and their percentages. The lower $\mathrm{R}^{2}$ were found for weight and percentage of bones in the belly and percentage of belly $(0.219,0.075$ and 0.240 , respectively).

Weight of belly correlated significantly positively with carcass weight but negatively with lean meat percentage in carcass (Table 3). Correlations between percentages of belly, meat, bones, fat in the belly and carcass weight were lower than those between meat, bones, intermuscular, subcutaneous fat in the belly and slaughter weight ( $r=-0.31$ to 0.25 ) of authors Vališ et al. (2005). These authors also report higher correlations of belly characteristics to lean meat percentage in carcass ( $r=-0.79$ to 0.92 ) than our results.

The relationship between carcass weight and belly traits was positive, which is documented by regression coefficients (Table 4). However, with increasing weight of belly is percentage of meat and bones decreasing while percentage of fat and skin increasing.

Table 3

Correlations between carcass traits

\begin{tabular}{lcccc}
\hline Trait & CW & WB & BF & LMP \\
\hline Weight of belly & $0.61^{* * *}$ & - & 0.16 & $-0.30^{* *}$ \\
Meat of belly & $0.52^{* * *}$ & $0.71^{* * *}$ & -0.09 & $0.26^{* *}$ \\
Fat and skin of belly & $0.43^{* * *}$ & $0.77^{* * *}$ & $0.27^{* *}$ & $-0.57^{* * *}$ \\
Bones of belly & 0.17 & $0.31^{* *}$ & 0.01 & 0.02 \\
Percentage of belly & 0.01 & $0.79^{* * *}$ & -0.09 & $-0.39^{* * *}$ \\
Percentage of meat in belly & -0.13 & $-0.37^{* * *}$ & $-0.32^{* *}$ & $0.65^{* * *}$ \\
Percentage of fat and skin in belly & 0.11 & $0.33^{* *}$ & $0.27^{* *}$ & $-0.62^{* * *}$ \\
Percentage of bones in belly & -0.02 & -0.19 & -0.05 & $0.22^{*}$ \\
\hline
\end{tabular}

${ }^{*} P<0.05,{ }^{*} P<0.01,{ }^{*} * P<0.001, \mathrm{CW}$ : carcass weight, WB: weight of belly, BF: backfat thickness, LMP: lean meat percentage

Table 4

Estimates of linear regression coefficients

\begin{tabular}{lcc}
\hline & Estimate & Standard Error \\
\hline Linear regression on carcass weight & & 0.00486 \\
Weight of belly, $\mathrm{kg}$ & 0.0621 & 0.00281 \\
Meat of belly, kg & 0.0283 & 0.00410 \\
Fat and skin of belly, kg & 0.0272 & 0.00094 \\
Bones of belly, kg & 0.0060 & 0.01097 \\
Percentage of belly, \% & 0.0201 & 0.55736 \\
Linear regression on weight of belly & & 0.61269 \\
Percentage of meat in belly, \% & -2.4321 & 0.19523 \\
Percentage of fat and skin in belly, \% & 2.6237 & -0.3647 \\
Percentage of bones in belly, \% & & \\
\hline
\end{tabular}

It can be concluded that the effect of sex on carcass characteristics of belly was significant. Gilts reached higher meat proportion in the belly than barrows which had higher content of subcutaneous and intermuscular fat. The influence of the genotype of terminal sire was also evident. This fact might be useful when decisions on breed or breed combination usage in 
hybridisation programme are made. The belly and its meatiness represent the potential to increase the lean meat percentage in pig carcasses.

\section{References}

Correa JA, Gariépy C, Marcoux M, Faucitano L (2008) Effects of growth rate, sex and slaughter weight on fat characteristics of pork bellies. Meat Sci 80, 550-554

Hermesch S (2008) Genetic relationships between composition of pork bellies and performance, carcase and meat quality traits. Animal 2, 1178-1185

Lévesque J (2003) Quality of pork belly: issue and elements of development. Report to the Centre de développement du porc du Québec, [in French]

Lo Fiego DP, Santoro P, Nanni Costa L, Minelli G (1992) Observation of fat characteristics in pork belly of heavy pigs. Sel Vet, 33, 917-925 [in Italian]

Marcoux M, Pomar C, Faucitano L, Brodeur C (2007) The relationship between different pork carcass lean yield definitions and the market carcass value. Meat Sci 75, 94-102

Person RC, McKenna DR, Griffin DB, McKeith FK, Scanga JA, Belk KE, Smith GC, Savell JW (2005) Benchmarking value in the pork supply chain: Processing characteristics and consumer evaluations of pork bellies of different thickness when manufactured into bacon. Meat Sci 70, 121-131

Pulkrábek J, Pavlík J, Smital J, Fiedler J, Houška L (1998) Quantification of changes of the carcass at various slaughter weight. Scientia Agric Bohem 29, 119-127

Pulkrábek J, Pavlík J, Vališ L, Vítek M (2006) Pig carcass quality in relation to carcass lean meat proportion. Czech J Anim Sci 51, 1, 18-23

SAS (2002/2003) SAS Institute Inc., Cary, NC, USA

Schinckel AP, Mills SE, Weber TE, Eggert JM (2002) A review of genetic and nutritional factors affecting fat quality and belly firmness. Proceedings of the national swine improvement federation: Conference and annual meeting. 5-6 December 2002, Nashville, TN, http://www.nsif.com/Conferences/2002/ ReviewGeneticNutritionalFactors.htm [last accessed 21.02.2011]

Stites CR, McKeith FK, Singh SD, Bechtel PJ, Mowrey DH, Jones DJ (1991) The effect of ractopamine hydrochloride on the carcass cutting yields of finishing swine. J Anim Sci 69, 3094-3101

Stupka R, Šprysl M, Pour M (2004a) Analysis of the formation of the belly in relation to sex. Czech J Anim Sci 49, 64-70

Stupka R, Šprysl M, Čitek J (2004b) Evaluation of the formation of the belly lean meat part in relation to the achieved carcass lean meat share. Scientia Agric Bohem 35, 104-110

Tholen E, Baulain U, Henning MD, Schellander K (2003) Comparison of different methods to assess the composition of pig bellies in progeny testing. J Anim Sci 81, 1177-1184

Tholen E, Brandt H, Henne H, Stork FJ, Schellander K (2001) Genetic foundation of AutoFOM-traits. Arch Tierz 44, 167-179

Vališ L, Pulkrábek J, Pavlík J, Vítek M, Wolf J (2005) Conformation and meatiness of pork belly. Czech J Anim Sci 50, 116-121

Walstra P, Merkus GSM (1995) Procedure for assessment of the lean meat percentage as a consequence of the new EU reference dissection method in pig carcass classification. DLO - Research Institute for Animal Science and Health Research Branch, Zeist, The Netherlands

Żak G, Tyra M (2006) Possibility of estimating belly and loin meat percentage in pigs based on data from dissection performed according to the Walstra and Merkus method. Rocz Nauk Zoot 33, 209-217 
Corresponding author:

Ivan Bahelka

email: bahelka@cvzv.sk

Department of Animal Breeding and Products Quality, Animal Production Research Centre, Hlohovská 2, 951 41 Lužianky, Slovak Republic 